\title{
14
}

\section{THE LIBERAL PARTY}

Nicholas Barry

The Liberal Party entered the 2019 election campaign in a similar position to 2016. Its previous three years in office had been characterised by internal instability, ideological conflicts, policy stagnation and, ultimately, a change in leadership, with Scott Morrison replacing Malcom Turnbull as prime minister. Such instability normally suggests a government heading to electoral defeat and this was reflected in polling that consistently showed Labor leading the two-party-preferred vote, albeit by a relatively small margin. As a result, many political commentators were surprised on election night when the Coalition was returned to office, with the Prime Minister himself declaring he had 'always believed in miracles'.

This chapter analyses the Liberal campaign in 2019 and explores its broader implications for the Liberal Party's ideological and organisational direction. After a brief summary of voting patterns, the first section analyses the key features of the party's campaign strategy, comparing it with the 2016 campaign. It argues that, although both campaigns were light on policy detail, the 2019 campaign was more negative in its orientation, made greater use of online campaigning and was more in keeping with traditional Liberal campaign themes. The second section focuses on party organisation. It argues that there was a significant shift in the lead-up to the campaign as sitting Liberal MPs publicly criticised the underrepresentation of women within the party and called for the introduction of quotas. It seems unlikely, however, that major reform will occur in this area in the foreseeable future given the hostility to quotas and feminism within powerful sections of the party. This section also examines 
disputes over the preselection process in New South Wales in the leadup to the 2019 campaign, arguing that it illustrates how difficult it is to democratise internal party processes. The third section of the chapter focuses on party ideology. Although some thought the Liberals would lose safe seats to moderate Independents in 2019, this occurred only in the seat of Warringah. Instead, the likely effect of the election was to reinforce the conservative ascendancy within the Liberal Party.

\section{The 2019 campaign}

Although the election result was widely described as a disaster for Labor, in terms of seat share, the overall picture throughout the country was one of relative stability. The Liberals gained four seats and the LNP gained two. Three of the Liberal gains and the two LNP gains were from Labor. The Liberals also won a seat previously held by an Independent. It was a similar story in terms of the Liberal Party's primary vote. According to the AEC, the party's share of the primary vote declined by around 2 per cent in Victoria and Western Australia, while there was a small increase of around 0.5 per cent in Queensland. The largest gain was in South Australia, where the Liberals achieved a 5.5 per cent increase as a result of the 16.9 per cent decline in the Centre Alliance vote. As discussed elsewhere in this volume, the capacity of the Liberals to retain and win marginal seats in Queensland and Tasmania was crucial to the outcome of the election, and it is likely this was partly a result of a significant increase in support for right-wing populist parties.

One of the major similarities between the 2016 and 2019 Liberal campaigns was the absence of major policy announcements. Turnbull's 2016 campaign focused strongly on corporate tax cuts that were set out in the 2016 federal Budget, and it featured few other major policies (Barry 2018: 278). Similarly, tax cuts announced in the 2019 federal Budgethanded down shortly before Morrison called the election-were key to the Morrison campaign. However, the 2019 Budget focused on income tax cuts, including a cash rebate of $\$ 1,080-\$ 1,215$ for workers earning $\$ 50,000-\$ 90,000$, targeting a group that received little from the 2016 Budget (Murphy 2019a). It also entailed a medium-term flattening of the income tax system, so those with yearly incomes of $\$ 45,000-\$ 200,000$ will pay a marginal tax rate of 30 per cent from 2024 (Karp 2019a), and $\$ 100$ billion of infrastructure spending over the next 10 years, focusing 
particularly on transport (Chan 2019). The large corporate tax cuts the government had previously supported were put aside (see Chapter 5, this volume).

One of the major internal criticisms of the 2016 Liberal campaign was that it was not negative enough (see Barry 2018: 280). In contrast, attacks on the trustworthiness of Opposition leader Bill Shorten and Labor's record on economic management were central to the 2019 campaign, and a major focus of Liberal campaign advertising. Labor's relatively detailed set of policy announcements, particularly its policies on negative gearing and dividend imputation, were particular targets for criticism. Multiple advertisements used the slogan 'Labor: It's the Bill Australia can't afford' (Liberal Party of Australia 2019a, 2019b), while others described Shorten as 'the greatest risk to Australia's economy in a generation' (Liberal Party of Australia 2019b). Mills (Chapter 23, this volume) suggests that aspects of the Liberal campaign in fact went beyond a merely negative campaign and became, instead, a scare campaign using misleading language such as 'retiree tax'. Liberal advertising also falsely claimed that Labor was planning to reintroduce a 'death tax' — a claim that was widely shared through social media (Murphy et al. 2019).

Another major difference between the 2016 and 2019 elections was the Liberal Party's capacity to engage in more effective online campaigning. One of the major criticisms of the 2016 campaign was that the party was lagging well behind Labor in this area (for example, Meers 2016; Barry 2018). However, this changed in 2019, with the Liberals running a more organised and sophisticated social media campaign. Reports suggest there were significantly higher levels of engagement with the Liberal Party's Facebook page and Scott Morrison's Instagram account than with Labor's Facebook page and Shorten's Instagram account (Bourke 2019). The videos posted on the Liberal Facebook site also received a much higher number of views than Labor's. There were 17,630,800 views of Liberal Facebook videos, while Labor Facebook videos were viewed only 5,940,500 times (Carson and Zion, Chapter 22, this volume; Knaus 2019).

The rise of online campaigning also led to concerns about the integrity of the campaign. The Liberal Party benefited from Facebook posts that falsely claimed Labor was planning to introduce an inheritance tax, although the posts were unauthorised and the Liberals denied they were responsible for them (Wroe 2019). Similarly, Liberal supporters used WeChat to target campaign messages at the Chinese community, spreading 
false information about Labor policies, with claims that Labor would increase the intake of refugees to 320,000 in 10 years and that this group of refugees will surpass Australia's entire Chinese immigrant population, and there will be more in the coming years and taxpayers will have to pay for it' (Zong, cited in Karp 2019b). Another message falsely claimed that Labor would extend the Safe Schools program to all schools around Australia and that the aim of the program was 'to teach students same sex sexual intercourse' and 'that the following vocabulary cannot be used: dad, mum, older brother, younger brother, older sister, younger sister, uncle, aunt, boy, girl, pregnant, and other gendered words' (Tomazin and Zhuang 2019). Although there is no indication the Liberal Party was officially involved in this campaign, the Liberal candidate (and now Member) for Chisholm, Gladys Liu, ran a similar campaign against Safe Schools on WeChat in 2016 when she chaired the Victorian Liberal Party's communities engagement committee (Hendrie 2016; Zhuang and Tomazin 2019).

Another notable feature of the 2019 campaign was the emergence of Advance Australia, a conservative response to left-wing activist organisation GetUp!. According to its website, Advance Australia 'is not a political party or aligned to any political organisation', but it is led by Gerard Benedet, who was previously a Liberal staffer (Seo 2019). Two of the four major campaign issues listed on its website were targeted at Labor policies (on dividend imputation and emissions reduction). Its two other areas of focus were also issues that were major concerns of the Liberal Party's conservative wing-preventing Australia Day being shifted from 26 January and changing Section 18C of the Racial Discrimination Act - while four of the five MPs it targeted for support during the 2019 campaign were conservative Liberals (Koslowski 2019). The emergence of this organisation is potentially significant because one of the Liberal Party's longstanding concerns-repeated in the aftermath of the 2016 campaign-was its weak capacity for on-theground campaigning (Brett 2003; Barry 2018), and the emergence of Advance Australia potentially helps address this deficit. Although the organisation was ultimately unsuccessful in one of its chief aims-to help Tony Abbott retain his seat of Warringah (Koslowski 2019)_Advance Australia reportedly attracted 32,000 members in its first six months and $\$ 1.2$ million in donations (Seo 2019). Its website also lists a number of wealthy backers on its advisory council, including Maurice Newman and Sam Kennard, so it is not impossible that it could become a significant campaign presence in the future. However, it is too early to reach any firm conclusions about what, if any, impact it will have in the long term. 
Although the Liberal campaign in 2019 departed in significant ways from its 2016 campaign, it is also important to note that some of the key themes were in keeping with a much longer Liberal tradition. In her work on the Liberal Party, Judith Brett (1992, 2003) has identified a continuous strand running through the rhetoric of the party and its prewar nonLabor predecessors. The rhetorical strategy is to identify the Labor Party with class war and sectional interests, while positioning the Liberal Party as the party that is about the national interest and/or the interests of hardworking 'mainstream' Australia. Brett has argued that, in the postwar period, the foremost Liberal exponents of this approach were Robert Menzies, with his emphasis on the 'Forgotten People', and more recently, John Howard, who was 'able to adapt the language and thinking carried in his party's political traditions to the circumstances of his political present' (Brett 2003: 184).

Although Morrison did not exhibit Menzies's or Howard's creative use of language, he did draw on themes that were in line with this longstanding Liberal tradition. In fact, the speech he gave at the Liberal Party campaign launch had striking similarities with the kind of language Menzies, Howard and others had used. Morrison emphasised that the Liberal Party stood for aspiration and the 'promise of Australia' in contrast to Labor's 'politics of envy'. His speech was filled with references to the importance of the family, the home and hard work, framed around Morrison's own family and experiences:

Mum is a woman of great and practical faith, quietly and patiently loving us, always. Life is about what you contribute, not what you accumulate. That's what mum and dad have taught me. It's about serving others, because in life, it's people that matter.

My family story is not uncommon in our country. Australians quietly going about their lives with simple, decent, honest aspirations. Get an education. Get a job. Start a business. Take responsibility for yourself, support others. Work hard. Deal with whatever challenges come your way. Meet someone amazing. I did, there she is, Jenny. Create a life and a family together. Work even harder to support them and give them the choices and hopefully, an even better life than the one that you have. Save for your retirement and your future. Strive, wherever possible, to be making a contribution rather than taking one. Leaving a legacy. (Morrison 2019) 
There are parallels here with Menzies's 'Forgotten People' speech. Alongside the emphasis on the family (and, by implication, the home), there is a clear emphasis on moral values, reflecting the longstanding Liberal belief that 'the middle-class ... is not just an economic class but a moral category whose members are defined by their political values, social attitudes and moral qualities as much as by their social and economic position' (Brett 1992: 41). This is reflected in the emphasis on contributing and not accumulating, saving for the future (cf. Brett 1992: 59-60) and leaving a better life for one's children. It is also a (presumably deliberate) attempt to distance the Liberals from Turnbull's emphasis on Australia as 'a nation that is agile, that is innovative, that is creative' (Turnbull and Bishop 2015), which has connotations of entrepreneurial activity and constant change in a digital economy.

In his victory speech on election night, Morrison emphasised that his election win was for the 'quiet Australians'. Although this was probably an attempt to draw a line between his prime ministership and the perceived rancour and leadership instability that had characterised Australian politics since 2007 (Murphy 2019b), there was an obvious similarity to Menzies's phrase 'the Forgotten People'. Thus, the 2019 campaign represented a return to some longstanding themes of Liberal campaigns in Australia, which was perhaps a reflection of Labor's renewed engagement with traditional issues of class and material inequality.

\section{Party organisation and the 2019 election}

The 2019 election also drew attention to a number of organisational issues confronting the Liberal Party. In particular, one of the marked features of the lead-up to the 2019 campaign was greater public discussion of the underrepresentation of women in the party. This issue had attracted some attention in the 2016 campaign because the number of women Liberal MPs was the lowest it had been since 1993 (Norman 2018a; see also Barry 2018: 285). However, at that time, few sitting federal MPs were prepared to comment publicly on the issue. In the lead-up to the 2019 election, this changed, with Liberal senators Jane Hume and Linda Reynolds and MPs Melissa Price and Julia Banks publicly drawing attention to the problem (Norman 2018a). 
The push for change gained further impetus following the leadership spill that resulted in Turnbull being replaced as prime minister. Many political commentators thought Morrison was less qualified for the job than foreign minister Julie Bishop, who was an experienced and popular politician, and they drew links between this and the Liberal Party's underrepresentation of women. Moreover, a number of women within the Liberal Party, including Senator Lucy Gichuhi and Julia Banks, publicly alleged that supporters of leadership candidate Peter Dutton had engaged in forms of bullying and intimidation during the leadership dispute (Yaxley 2018). Minister for Women Kelly O'Dwyer supported these claims, commenting that 'it is clear to me that people were subjected to threats and intimidation and bullying' (Norman 2018b).

One of the Liberal Party's leading internal critics, Julia Banks, the Member for Chisholm, decided to quit the Liberals following the leadership change and sit as an Independent. In her speech to the parliament announcing this decision, Banks stated:

Equal representation of men and women in this parliament is an urgent imperative which will create a culture change. There's the blinkered rejection of quotas and support of the merit myth, but this is more than a numbers game. Across both major parties, the level of regard and respect for women in politics is years behind the business world. There is also a clear need for an independent whistleblower system, as found in many workplaces, to enable reporting of misconduct of those in power without fear of reprisal or retribution. Often when good women call out or are subjected to bad behaviour, the reprisals, backlash and commentary portray them as the bad ones: the liar, the troublemaker, the emotionally unstable or weak, or someone who should be silenced. (Banks, in Commonwealth Parliament of Australia 2018)

In this way, Banks drew attention to the effect of the culture and behaviour within the parliament on female underrepresentation, while calling for the introduction of quotas to bring about more equal representation. Liberal frontbencher Sussan Ley also suggested this was a reform that should be considered (Murphy 2018). This is particularly notable as Ley became Minister for the Environment following the election, which means that, for the first time in recent memory, there is a sitting federal Liberal frontbencher who has seriously raised the prospect of introducing quotas. 
There is substantial evidence that quotas are an effective way of addressing a gender imbalance in the representation of MPs (Baird and Bold 2019). However, the idea of affirmative action underlying quotas sits uneasily with Liberal Party ideology, as affirmative action reflects an acknowledgement that structural inequalities have played a role in generating the underrepresentation of women. Acknowledging this fact sits uneasily with both neoliberalism, with its emphasis on individuals competing in an unfettered free market, and conservatism, which is hostile to feminism and opposed to forms of intervention that challenge existing hierarchies. It is perhaps unsurprising that other parties on the right around the world tend to have a problem with the representation of women. For example, after the May 2019 elections for the European Parliament, all parties on the left and centre-left had at least 40 per cent female representation (Politico 2019). In contrast, most parties on the right and centre-right had female representation rates of less than 30 per cent (the exception was the Europe of Freedom and Direct Democracy group, which had 40.48 per cent). Given the broader ideological context, and the fact Morrison has explicitly rejected calls for quotas (SBS 2018), it is hard to imagine any significant action on this issue occurring in the next three years. Nonetheless, recent events suggest influential women within the Liberal Party are becoming increasingly concerned about underrepresentation and are prepared to publicly call for reform.

Another ongoing organisational issue for the Liberal Party relates to preselection. Over the past 10 years, the party has faced criticism, particularly in its NSW division, for a lack of democracy in the preselection process (Staley 2008: 23; Reith 2011: 23; Barry 2018: 161, 163-64). In the wake of the 2016 election, there was a strong push to adopt proper membership plebiscites for preselections in the NSW division, as recommended by a 2014 review led by former prime minister John Howard (Nicholls 2014). This culminated in the 'Warringah motion', which proposed the adoption of a 'one-vote, one-member approach' to membership involvement in preselections (McNally 2018). This motion was initiated by the Warringah branch of the party and backed by former prime minister and member for Warringah Tony Abbott (Chan 2017). The motion was passed with the support of 61 per cent of delegates attending the NSW Liberal Futures convention, which was a special convention held in 2017 to discuss preselection reforms (Knaus and Chan 2017). However, it was subsequently rejected at the annual general meeting of the NSW division in 2018, which instead endorsed the 'Bennelong 
motion', which was a 'watered-down' alternative that gave party members the ability to preselect candidates while leaving 'around 10 per cent of the preselection vote' with the party hierarchy (McNally 2018).

This shows how difficult it is to achieve internal party organisational reform, particularly if the reforms in question involve a 'democratising' of internal party processes. The problem is that it is difficult to achieve reform without winning agreement from those wielding power within the party under the existing structures. Because existing powerbrokers generally benefit from preserving the status quo, they are likely to be reluctant to embrace reform (see Coghlan and Denton 2012; Gauja 2012, 2017; Miragliotta 2013; Barry 2015, 2018). This is partly reflected in the fate of the Warringah motion, which was largely being pushed by the party's right faction (which was likely to increase its power if preselection processes were democratised) and opposed by the moderate and centre-right factions, which currently wield most power within the NSW division (Nicholls 2017). ${ }^{1}$ Nonetheless, the reform that occurred-even in its watered-down form-still had some significance, even if did not go as far as advocates of the Warringah motion desired. In the wake of the Bennelong motion being passed, Abbott, for example, stated: 'The Liberal Party is still too much of an insiders' club, but it's much less of an insiders' club than it was' (cited in McNally 2018). Ultimately, the reform contributed to the defeat of Senator Jim Molan at the 2019 election. Molan, who was actually a supporter of party democratisation, ended up being preselected for the unwinnable fourth position on the Coalition's NSW Senate ticket (Hunter and Loussikian 2018).

A final twist in the recent history of Liberal Party preselection reform in New South Wales was Scott Morrison's intervention to convince the State executive to cancel preselection votes in four seats so the sitting members were automatically re-endorsed (see Gauja and Taflaga, Chapter 4, this volume; Tillett 2018). The primary aim was to save conservative MP Craig Kelly, who was reportedly in danger of being dumped as the Liberal candidate for Hughes. Morrison's intervention was clearly against the spirit of party democratisation and it further illustrates how difficult it is to achieve meaningful reform. Even when watered-down measures such

1 As is often the case with internal party debates over organisational reform, there were other issues at play. In particular, the push for reform became entangled in the acrimony associated with the leadership dispute between Tony Abbott and Malcolm Turnbull (Chan 2017), while there were also concerns over potential branch-stacking (Nicholls 2017). 
as the Bennelong motion are adopted, there will always be a temptation for State executive intervention to cancel preselections or overturn decisions made at the local level, particularly when the authority of the parliamentary leader is at stake.

\section{Party ideology}

The 2019 election result also has important implications for the ideological direction of the Liberal Party and its place in the party system. The major points of disagreement within the Liberals are not over economic policy, where there is support for a broadly neoliberal approach, but over social and environmental issues. ${ }^{2}$ When Turnbull took the party leadership from Abbott in the lead-up to the 2016 campaign, some believed this would mean a change in the ideological direction of the party as Turnbull had more progressive views on social and environmental issues than Abbott and many other Liberal MPs. However, from the outset of his prime ministership, Turnbull was constrained by internal forces within the Coalition. To win the leadership and become prime minister, he made agreements with conservative Liberal MPs and the Nationals to retain Abbott's proposed plebiscite on same-sex marriage, rather than have a vote on the issue in parliament (Hartcher 2019b). Ultimately, the catalyst for the end of his prime ministership was climate change policy, which also ended his time as Opposition leader in 2009. Turnbull's energy policy, the NEG, aimed to bring about a 26 per cent cut in carbon emissions by 2030 (Knaus 2018). Although a majority of the party room supported the policy, Abbott and a number of other conservative MPs threatened to cross the floor on the Bill. As a result, Turnbull dropped the reduction target from the NEG; however, this was not enough to save him from being deposed as prime minister following a leadership challenge led by conservative MPs.

2 There is not space in this chapter for a detailed account of what is meant by the terms 'conservative' and 'progressive'. However, in brief, a conservative in this context refers to an MP who wants to preserve cultural traditions (or, more accurately, their perception of a particular set of cultural traditions) against the demands of those who are pushing for 'progressive' reforms. The 'progressives' are generally aiming for social reforms that improve the status of disadvantaged and oppressed minorities and environmental reforms aimed at reducing carbon emissions and promoting environmental sustainability. In recent times, core issues of division within the Liberal Party (and beyond) have occurred over issues such as marriage equality, the Racial Discrimination Act and climate change, which have pitted conservative MPs against 'moderate' MPs who are somewhat more progressive on social and environmental issues. 
The constraints Turnbull faced as Liberal leader and the fact he was replaced with the more ideologically conservative Morrison clearly illustrated the ascendancy of conservative forces within the Liberal Party on social and environmental issues. In light of this, some commentators (for example, Hartcher 2019a) thought this might give Independent candidates more of a chance to win some blue-ribbon Liberal seats where voters were economically conservative but more progressive on social and environmental issues. The Wentworth by-election, triggered by Turnbull's resignation from parliament, reinforced this belief, with former Australian Medical Association president Kerryn Phelps winning the safe Liberal seat as an Independent, running on a campaign that emphasised the importance of action on climate change. With a number of highprofile socially progressive but economically conservative Independents running in similar seats around the country-including Zali Steggall in Warringah, Oliver Yates in Kooyong and ex-Liberal MP Julia Banks in Flinders-and the loss of Indi to Cathy McGowan in 2013 and Mayo to NXT candidate Rebekha Sharkie in 2016 (Hartcher 2019a), it seemed possible that the Liberal Party was facing the defection of more moderate voters who were alienated by the conservative direction of the party, particularly on environmental issues. ${ }^{3}$

The election did not, however, ultimately result in an influx of progressive Independents in safe Liberal seats. Steggall won the seat of Warringah from Abbott, who experienced a 12.64 per cent decline in his first-preference vote, and there were significant results in the formerly safe Liberal seats of Indi (where Independent candidate Helen Haines replaced the retiring McGowan) and Mayo (where Sharkie was returned, now for the Centre Alliance). However, sizeable swings in other seats did not result in victory for progressive Independent candidates. For example, an 8.24 per cent decline in the Liberals' first-preference vote in Kooyong did not result in victory for Yates, while Phelps was defeated by Dave Sharma in Wentworth, despite a 14.82 per cent fall in the Liberal first-preference vote (compared with the 2016 election). Overall, the results of the 2019 election do not demonstrate an imminent threat to the Liberal Party from progressive Independents in blue-ribbon seats. However, the rise of highprofile challengers, the fall in the Liberal first-preference vote in some of

3 Although she was not as strongly supportive of action on climate change as some of the other Independents, Louise Stewart in Curtin could possibly be added to this list, as could the Greens candidate in Kooyong, Julian Burnside-a high-profile barrister and campaigner for a more humanitarian approach to refugee policy. 
these seats, the loss of Warringah and the likelihood that climate change will become an increasingly salient issue in future campaigns do suggest there is potential for change in the near future.

Because the Liberals went to the 2019 election with relatively few major policy commitments, it is unclear what their policy agenda for the next three years will be beyond the income tax cuts and transport spending announced in the 2019 Budget. However, there are a number of reasons to think the party is likely to move further to the right. Having deposed the Liberal Party's most high-profile moderate, Malcolm Turnbull, as party leader and won an unexpected election victory under Morrison, conservative forces within the Liberal Party are likely to have been emboldened to pursue a conservative agenda. Adding to this is the retirement of other high-profile moderates such as Julie Bishop, Julia Banks and Kelly O'Dwyer. Combined with the importance of PHON and UAP preferences in deciding the election in key marginal seats, it seems likely that conservative forces will be in the ascendant.

Early indications seem to bear this out. There had been be a renewed push by some within the Liberal Party to amend Section 18C of the Racial Discrimination Act to remove the reference to speech that offends. This was one of the major issues on the agenda during the Abbott Government's first term, and it was also part of the election manifesto of the IPA that was sent to Coalition MPs in the lead-up to the 2019 election (Bennett, Chapter 21, this volume; Crowe 2019). On the issue of climate change, the collapse of the NEG left Australia in an unstable position on energy policy. Given this uncertainty has attracted the ire of business groups-which are one of the core Liberal constituencies-the Morrison Government is likely to face pressure to act on this issue. However, balanced against this is the political strength of the fossil fuel industry, opposition to major cuts in carbon emissions from conservative Liberal MPs, the fact climate change policy played a key role in the demise of three of Australia's past four prime ministers and Morrison's past support for coal.

\section{Conclusion}

Despite the internal instability and policy stagnation of its second term in office, the Coalition Government was returned for a third term on the back of a highly negative small-target strategy that made Labor's tax policies and leadership the main focus. The Liberal Party significantly 
improved its digital campaigning in 2019, but its attacks on Labor drew on longstanding themes in its own campaign history. Although there were some signs that 2019 might mark a shift in attitudes on the underrepresentation of women within the party and the start of a process of ideological fragmentation, ultimately, no significant change occurred in either direction. Considering the authority Prime Minister Scott Morrison is likely to wield within the party on the back of an election victory that was perceived to be a 'miracle', the ideological and organisational status quo seems likely to persist for at least another three years.

\section{References}

Baird, Julia and Sam Bold. 2019. 'Conservative parties around the world have a problem —and women are losing patience'. $A B C$ News, 8 February. www.abc. net.au/news/2019-02-07/women-in-parliament-labor-liberal/10783234.

Barry, Nicholas. 2015. 'Party reviews and organisational reform'. In Contemporary Australian Political Party Organisation, edited by Narelle Miragliotta, Anika Gauja and Rodney Smith, 154-68. Melbourne: Monash University Press.

Barry, Nicholas. 2018. 'The Liberal campaign'. In Double Disillusion: The 2016 Australian Federal Election, edited by Anika Gauja, Peter Chen, Jennifer Curtin and Juliet Pietsch, 277-96. Canberra: ANU Press. doi.org/10.22459/ dd.04.2018.12.

Bourke, Latika. 2019. 'How the Liberals beat Labor at its own game'. Sydney Morning Herald, 26 May. www.smh.com.au/federal-election-2019/how-theliberals-beat-labor-at-its-own-game-20190523-p51qki.html.

Brett, Judith. 1992. Robert Menzies' Forgotten People. Sydney: Sun Australia.

Brett, Judith. 2003. Australian Liberals and the Moral Middle Class. Melbourne: Cambridge University Press. doi.org/10.1017/CBO9780511481642.

Chan, Gabrielle. 2017. 'Liberals warned party will split if NSW preselection reforms rejected'. The Guardian, 17 July. www.theguardian.com/australia-news/2017/ jul/17/liberals-warned-party-will-split-if-nsw-preselection-reforms-rejected.

Chan, Gabrielle. 2019. 'Roads, rails and car parks get $\$ 100 \mathrm{bn}$ infrastructure spend in Australian budget—but over a decade'. The Guardian, 2 April. www.theguardian.com/australia-news/2019/apr/02/australia-federal-budget2019-infrastructure-frydenberg-treasurer-budget. 
Coghlan, Jo and Scott Denton. 2012. 'Reviewing Labor's Internal Reviews 1966-2010: Looking Forwards, Looking Backwards'. Melbourne Journal of Politics 35: 19-38.

Commonwealth Parliament of Australia [Hansard]. 2018. House of Representatives Parliamentary Debates, Official Hansard, 27 November, p. 11571.

Crowe, David. 2019. 'Coalition MPs urged to sell the ABC and support a flat tax in IPA call'. Sydney Morning Herald, 16 April. www.smh.com.au/federalelection-2019/coalition-mps-urged-to-sell-the-abc-and-support-a-flat-taxin-ipa-call-20190416-p51enu.html.

Gauja, Anika. 2012. 'The "Push" for Primaries: What Drives Party Organisational Reform in Australia and the United Kingdom?'. Australian Journal of Political Science 47(4): 641-58. doi.org/10.1080/10361146.2012.731490.

Gauja, Anika. 2017. Party Reform: The Causes, Challenges and Consequences of Organisational Change. Oxford: Oxford University Press. doi.org/10.1093/ acprof:oso/9780198717164.001.0001.

Hartcher, Peter. 2019a. 'How conservatives stole the Liberal Party'. Sydney Morning Herald, 2 February. www.smh.com.au/national/how-conservativesstole-the-liberal-party-20190201-p50v6i.html.

Hartcher, Peter. 2019b. "“He sold everything he believed in”: The price Turnbull paid to become prime minister'. Sydney Morning Herald, 28 March. www. smh.com.au/politics/federal/he-sold-everything-he-believed-in-the-priceturnbull-paid-to-become-prime-minister-20190321-p516ad.html.

Hendrie, Doug. 2016. 'How a Chinese-language social media campaign hurt Labor's chances'. The Guardian, 9 July. www.theguardian.com/australia-news/ 2016/jul/09/how-a-chinese-language-social-media-campaign-hurt-laborselection-chances.

Hunter, Fergus and Kylar Loussikian. 2018. 'Surprise Liberal pre-selection result spells end of Jim Molan's Senate career'. Sydney Morning Herald, 24 November. www.smh.com.au/politics/federal/surprise-liberal-preselection-result-spellsend-of-jim-molan-s-senate-career-20181124-p50i3t.html.

Karp, Paul. 2019a. 'Coalition budget woos low and middle-income earners with $\$ 19.5$ bn tax cuts'. The Guardian, 2 April. www.theguardian.com/australianews/2019/apr/02/coalition-federal-budget-2019-woos-low-and-middleincome-earners-with-195bn-tax-cuts-in-budget. 
Karp, Paul. 2019b. 'Penny Wong blasts "malicious" WeChat campaign spreading fake news about Labor'. The Guardian, 7 May. www.theguardian.com/ australia-news/2019/may/07/penny-wong-blasts-malicious-wechat-campaignspreading-fake-news-about-labor.

Knaus, Christopher. 2018. 'Australian PM dumps key climate policy to stave off leadership revolt'. The Guardian, 20 August. www.theguardian.com/australianews/2018/aug/20/australian-pm-dumps-key-climate-policy-to-stave-offleadership-revolt.

Knaus, Christopher. 2019. 'Liberal Party also beat Labor on Facebook in 2019 Australian federal election'. The Guardian, 4 June. www.theguardian.com/ australia-news/2019/jun/04/liberal-party-also-beat-labor-on-facebook-in2019-australian-federal-election.

Knaus, Christopher and Gabrielle Chan. 2017. 'Tony Abbott-backed motion for NSW Liberal preselections wins party support'. The Guardian, 23 July. www.theguardian.com/australia-news/2017/jul/23/tony-abbott-backedmotion-for-nsw-liberal-preselections-wins-party-support.

Koslowski, Max. 2019. 'Advance Australia, the conservative GetUp!, comes to Tony Abbott's rescue'. Sydney Morning Herald, 13 March. www.smh.com. $\mathrm{au} /$ politics/federal/advance-australia-the-conservative-getup-comes-to-tonyabbott-s-rescue-20190312-p513ht.html.

Liberal Party of Australia. 2019a. 'The Bill Australia Can't Afford'. YouTube, 15 April. www.youtube.com/watch?v=i5saOqqjTs0.

Liberal Party of Australia. 2019b. 'The Bill Australia Can't Afford'. YouTube, 22 April. www.youtube.com/watch?v=F_1a1KoYi-U.

McNally, Lucy. 2018. 'Tony Abbott's Warringah motion for more conservative control in NSW Liberals fails to pass'. $A B C$ News, 11 February. www.abc.net. au/news/2018-02-10/warringah-motion-fails-to-pass/9419172.

Meers, Daniel. 2016. 'Angry Tasmanian Senator Eric Abetz takes aim at Coalition election campaign'. Mercury, [Hobart], 15 July. www.news.com.au/national/ federal-election/angry-tasmanian-senator-ericabetz-takes-aim-at-coalitionelection-campaign/news-story/4c3982ff4f91c125a83b3e326a38474e.

Miragliotta, Narelle. 2013. 'Explaining the (Lack of) Use of Radical Candidate Selection Methods by Australia's Major Parties'. Australian Journal of Politics and History 59(1): 113-26. doi.org/10.1111/ajph.12007.

Morrison, Scott. 2019. 'Coalition campaign launch, [Speech], 12 May'. Canberra: Liberal Party of Australia. www.liberal.org.au/latest-news/2019/ 05/12/coalition-campaign-launch. 
Murphy, Katharine. 2018. 'Liberal Party should consider quotas for female MPs, Sussan Ley says'. The Guardian, 6 September. www.theguardian.com/australianews/2018/sep/06/liberal-party-should-consider-quotas-for-female-mpssussan-ley-says.

Murphy, Katharine. 2019a. 'Budget 2019: Scott Morrison breaks with past budget catastrophes in bid to save his skin'. The Guardian, 2 April. www.theguardian. com/australia-news/2019/apr/02/australia-federal-budget-2019-scottmorrison-election-josh-frydenberg-coalition-labor.

Murphy, Katharine. 2019b. 'Scott Morrison won the unwinnable election. Now the hard part begins'. The Guardian, 22 May. www.theguardian.com/ australia-news/2019/may/22/scott-morrison-won-the-unwinnable-electionnow-the-hard-part-begins.

Murphy, Katharine, Christopher Knaus and Nick Evershed. 2019. "'It felt like a big tide": How the death tax lie infected Australia's election campaign'. The Guardian, 8 June. www.theguardian.com/australia-news/2019/jun/08/it-feltlike-a-big-tide-how-the-death-tax-lie-infected-australias-election-campaign.

Nicholls, Sean. 2014. 'Former prime minister John Howard backs democratic reform of NSW Liberal Party'. Sydney Morning Herald, 23 July. www.smh. com.au/national/nsw/former-prime-minister-john-howard-backs-democraticreform-of-nsw-liberal-party-20140723-zvyvk.html.

Nicholls, Sean. 2017. 'More than $\$ 13,000$ spent on member registrations in bid to "buy" the Liberal Party'. Sydney Morning Herald, 20 July. www.smh.com. $\mathrm{au} /$ national/nsw/more-than-13000-spent-on-member-registrations-in-bidto-buy-the-liberal-party-20170720-gxf9jz.html.

Norman, Jane. 2018a. 'Liberals' lack of female representation is costing them votes, so senior women are speaking out'. $A B C$ News, 27 February. www.abc.net.au/ news/2017-11-27/liberal-party-lack-of-women-costing-votes/9175150.

Norman, Jane. 2018b. 'Peter Dutton's backers refused to leave Liberal Party members' offices, demanded they reveal votes during spill'. $A B C$ News, 7 September. www.abc.net.au/news/2018-09-07/nasty-tactics-dutton-backersliberal-spill-revealed/10212110.

Politico. 2019. 'The European Parliament's gender gap'. Politico, 20 April. www.politico.eu/interactive/share-of-women-meps-by-political-group-andcountry/.

Reith, Peter. 2011. Review of the 2010 Federal Election. Canberra: Parliament of Australia. parlinfo.aph.gov.au/parlInfo/search/display/display.w3p;query= Id\%3A\%22library\%2Fpartypol\%2F934846\%22. 
Seo, Bo. 2019. 'GetUp and Advance Australia go head-to-head'. Australian Financial Review, 23 April. www.afr.com/news/politics/national/getup-andadvance-australia-go-head-to-head-20190418-p51fb3.

Special Broadcasting Service (SBS). 2018. 'Morrison rejects gender quotas to boost female numbers'. SBS News, 11 September. www.sbs.com.au/news/ morrison-rejects-gender-quotas-to-boost-female-numbers.

Staley, Tony. 2008. Review of the 2007 Federal Election Campaign \& Review of the Liberal Party Federal Constitution. Canberra: Liberal Party of Australia.

Tillett, Andrew. 2018. 'Scott Morrison's ugly win shuts down Malcolm Turnbull support for dumping Craig Kelly'. Australian Financial Review, 3 December. www.afr.com/news/politics/scott-morrisons-ugly-win-shuts-down-malcolmturnbull-support-for-dumping-craig-kelly-20181203-h18nxt.

Tomazin, Farrah and Yan Zhuang. 2019. 'Safe Schools scare campaign targets Chinese-Australian voters'. Sydney Morning Herald, 27 April. www.smh. com.au/federal-election-2019/safe-schools-scare-campaign-targets-chineseaustralian-voters-20190427-p51hrk.html.

Turnbull, Malcolm and Julie Bishop. 2015. 'Vote on the Liberal Party leadership, Press conference, Parliament House, Canberra, 15 September'. [Transcript]. www.malcolmturnbull.com.au/media/transcript-vote-on-the-liberal-partyleadership.

Wroe, David. 2019. 'Labor demands Facebook remove "fake news" posts about false death tax plans'. Sydney Morning Herald, 19 April. www.smh.com.au/ federal-election-2019/labor-demands-facebook-remove-fake-news-postsabout-false-death-tax-plans-20190419-p51fpk.html.

Yaxley, Louise. 2018. 'Liberal Party grappling with how to boost number of women in federal parliament'. $A B C$ News, 11 September. www.abc.net.au/ news/2018-09-11/liberal-women-quotas/10230298.

Zhuang, Yan and Farrah Tomazin. 2019. 'Labor asks questions of WeChat over doctored accounts, "fake news". Sydney Morning Herald, 6 May. www.smh. com.au/national/labor-asks-questions-of-wechat-over-doctored-accountsfake-news-20190506-p51kkj.html. 
This text is taken from Morrison's Miracle: The 2019 Australian Federal Election, edited by Anika Gauja, Marian Sawer and Marian Simms, published 2020 by ANU Press, The Australian National University, Canberra, Australia.

doi.org/10.22459/MM.2020.14 